(C) 2017

Маркіна I. А., доктор економічних наук, професор

Полтавська державна аграрна академія

\title{
РОЗВИТОК ОРГАНІЗАЦІЙНИХ СТРУКТУР ТА ПРОГРАМ СПІВУЧАСТІ В СИСТЕМІ АГРАРНОГО ЗЕМЛЕКОРИСТУВАННЯ
}

\section{Рецензент - доктор економічних наук, професор Х. 3. Махмудов}

\begin{abstract}
Розроблено кластерну модель дуалістичного (традииійна та органічна продукиія) розвитку землекористування в Украӥні. Принциповою відмінністю від існуючих моделей $\epsilon$ наявність Національного науково-виробничого агроекологічного парку, регіональних наукових (економічних) центрів розвитку сільських територій та зміщення акценту ролі держави на реалізацію економічних функцій як агента земельних інтересів. Представлена система інформачійного провайдингу в управлінні земельними ресурсами аграрного сектору економіки. Запропоновано концеепцію розвитку державно-приватного партнерства в системі землекористування, що заснована на агрохімічному, меліоративному, логістичному та збутовому напрямах та має на меті забезпечення поєднання можливостей мікро-, мініагентів, спільних агентів та держави, в тому числі із залученням коштів регіональних $і$ глобальних агентів, на компліментарній основі з приводу раціонального землекористування та підвищення прямих $і$ непрямих доходів всіх представників груп земельних інтересів.
\end{abstract}

Ключові слова: організаційні структури, програми співучасті, землекористування, аграрний сектор економіки, дуалістичний розвиток.

Постановка проблеми. В умовах децентралізації влади та євроінтеграційних спрямувань України агент держава для всіх інших агентів земельних інтересів більше партнер, ніж контролер. Усвідомлення цього змінює пріоритети в земельних відносинах, a раціональне використання земельних ресурсів аграрного сектору економіки України - свій координаційносубординаційний формат. За логікою наших досліджень більшої ролі набуватимуть спільні агенти, що через «єдиний голос» зможуть донести свою позицію навіть найдрібніших землевласників i землекористувачів до будь-якого агента земельних інтересів. Особливо необхідним $\epsilon$ визначення певних граней співпраці держави як партнера 3 даними агентами.

Аналіз останніх досліджень i публікацій, у яких започатковано розв'язання проблеми. Глобалізація $є$ колосальним стимулом до галузевої консолідації [3, 7], що $\epsilon$ однією 3 причин формування сучасних агрохолдингів. Одночасно 3 цим, вони займаються монокультурою, а орієнтація на більш вигідні зернові та олійні культури посилює залежність країни від світового ринку [2, 8, 9, 10]. Втрачаючи при цьому перспективні конкуренті переваги, агрохолдинги розвиваються в Україні за моделлю «орендних латифундій», монополізуючи землекористування 3 усіма витікаючими 3 цього наслідками. В даному відношенні світовий досвід вже давно продемонстрував переваги кооперативного i кластерного підходів до організації виробництва, переробки і збуту сільгосппродукції $[1,4,12]$. Слід зазначити, що за кластерної організації агропромислового виробництва малі, середні та великі підприємства агробізнесу - учасники кластерних утворень, - досягають порівняного 3 агрохолдингами рівня конкурентоспроможності, а сам інтеграційний механізм кластеризації на основі концентрації агропромислового виробництва та спеціалізації його учасників формує «точки зростання» регіональних і місцевих економік [11]. Дані проблеми актуалізують проведення даного дослідження.

Невирішеними раніше частинами загальної проблеми є взаємодія всіх суб'єктів земельних відносин щодо формування паритетної політики розподілу доданої вартості та його інформаційної складової.

Мета дослідження - дослідити можливості моделювання організаційних структур та розвиток державно-приватного партнерства в системі управління земельними ресурсами України.

Завдання дослідження:

- обгрунтувати організаційну структуру УЗР у контексті дуалістичного розвитку на основі кластеризацї;

- сформувати засади державно-приватного партнерства в системі землекористування України;

- визначити організаційні засади взаємодії суб'єктів земельних відносин.

Методи досліджень: економіко-статистичний для поєднання якісного та кількісного аспектів; нейронних мереж - для обробки й узагальнення статистичних даних і їх відображення в найбільш інформативній формі; програмно-цільовий - для 


\section{ЕКОНОМІКА}

визначення інструментарію ефективного управління земельними ресурсами на державному рівні; системний підхід - для обгрунтування організації раціонального використання земельних ресурсів.

Результати досліджень. Виходячи 3 дуалістичної моделі розвитку національного землеробства в Україні, можлива ii побудова на кластерній основі. При цьому ядром кластеру на рівні області мають бути об'єкти, що безпосередньо контактують і 3 виробником, i зі споживачем. На наше переконання, будь-які державні надбудови посередницького характеру неефективні. Тому найбільш реалістичний варіант - асоціації землекористувачів та землевласників, представлених як окремими підприємцями, так і їх об'єднаннями.

Керівником центру має бути президент галузевої (наприклад, зернової, садівничої, ягідної, тепличної, горіхової, соєвої, рапсової, картопляної тощо) або територіальної (обласної чи міжобласної) асоціації землевласників і землекористувачів. Мета керівника центру - підвищення інтелектуальної складової вартості земельних ресурсів аграрного сектору економіки до рівня кращих світових аналогів. Керівник центру є зв'язуючим ланцюгом між наукою (вищими навчальними та науково-дослідними закладами, державними агрохімічними лабораторіями), державою (керівництво області) та недержавними організаціями (союзами, спілками, федераціями, дорадчими службами, лабораторіями тощо). Між керівником центру $є$ прямий зв'язок зі структурами районного масштабу, з якими також проводиться безпосередня робота вищих навчальних та науково-дослідних закладів, державних агрохімічних лабораторій та вищезазначених недержавних організацій.

Подібні структури районного масштабу та безпосередньо керівник центру пов'язані 3 організаторами і виконавцями робіт, суб'єктами господарювання та представниками сільських населених пунктів.

Основні функції центрів: формування права «єдиного голосу» від імені багатьох дрібних мініта мікроагентів; бізнес-планування щодо реалізації проектів у землеробстві; адміністрування інфраструктурних, органічних та екологічних проектів. Слід зазначити, що глобальні аграрні проекти, наприклад, екологізація землеробства, не можуть бути якісно реалізовані без суттєвого наукового супроводу, що фактично можливо за потужної національної науково-виробничої консолідації. На наше переконання, дані регіональні центри мають координуватися Національним науково-виробничим агроекологічним парком (далі ННВАП), що за різних ініціатив було запропоновано сформувати на базі ПП «Агроекологія» Шишацького району Полтавської області як флагмана вітчизняного органічного руху. Слабкими місцями підприємства в якості парку може бути саме провайдинг агроекологічних інновацій через концентрацію на виробничій діяльності. Тому нами пропонується координаційне поєднання виробничої та аналітикоконсультаційної діяльності в партнерстві 3 Асоціацією Український клуб аграрного бізнесу (найбільше в країні, прогресивно налаштоване, представлене в більшості регіонів України, суспільно-професійне об'єднання компаній аграрного сектору економіки України, що надає широкий спектр послуг для агробізнесу), яка може представляти один 3 найбільш потужних дослідницьких i презентаційних майданчиків аграрного бізнесу України. При цьому основною метою ННВАП має бути пропагування еталонних технологій землеробства. Основні задачі ННВАП: сприяння комунікації між споживачем i виробником продукції, споживачем і розробником інноваційних технологій, зокрема пов'язаних 3 органічним землеробством; налагодження зв'язків між регіональними науковими (економічними) центрами розвитку сільських територій, в тому числі і закордонних; участь у наданні повного спектру послуг для аграрних, продовольчих i ресурсних компаній.

Оскільки у відповідності до Закону України «Про наукові парки», науковий парк - це юридична особа, що створюється 3 ініціативи вищого навчального закладу та/або наукової установи шляхом об'єднання внесків засновників для організації, координації, контролю процесу розроблення і виконання проектів наукового парку [5], структура ННВАП, за авторською думкою, наступна: ПП «Агроекологія»; Український клуб аграрного бізнесу; Полтавська державна аграрна академія; Державна установа «Держтрунтохорона». ННВАП має стати суттєвим структурним елементом кластерної моделі організації дуалістичного розвитку землекористування в Україні (рис. 1), що як самостійно, так і через регіональні наукові (економічні) центри розвитку сільських територій забезпечує агровиробників та ïx об'єднання інформаційною підтримкою екологопрогресивних технологій землекористування, виконує інспекцію та контроль за виробництвом екологічної продукції, проводять 3 ними консультаційну діяльність за двома основними напрямами: органічне землеробство; традиційне землеробство на максимально екологобезпечній енергоощадній основі. 


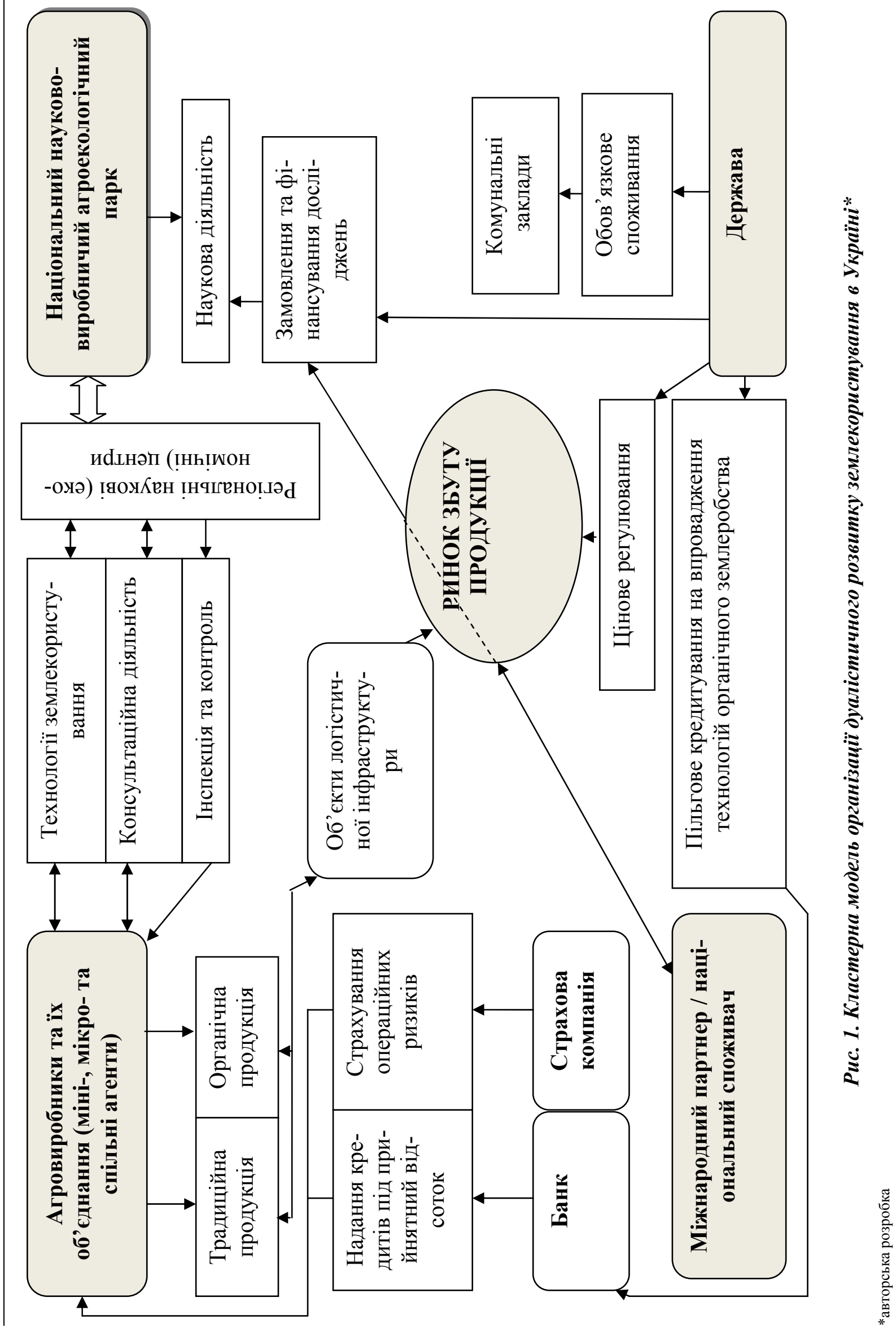




\section{ЕКОНОМІКА}

Відповідно, дані проекти в призмі реалізації економічної функції держави, як агента земельних інтересів, підтримуються через: цінове регулювання органічної та традиційної продукції; замовлення та фінансування досліджень ННВАП; обов'язкове споживання низкою комунальних закладів (дитячі садки, школи, лікарні, будинки людей похилого віку, інтернати тощо) органічної продукції; пільгове кредитування проектів із впровадження технологій органічного землеробства (через банки). Щодо ролі міжнародних партнерів як представників регіональних та глобальних агентів земельних інтересів, то їх участь може бути як пов'язаною із замовленням науковотехнічних послуг у ННВАП, так і з придбанням продукції через ринки їх збуту.

Запропонована кластерна модель організації дуалістичного розвитку землекористування в Україні та наявність в ній Національного науково-виробничого агроекологічного парку та регіональних наукових (економічних) центрів розвитку сільських територій дають змогу вирішити проблему інформаційного провайдингу в управлінні земельними ресурсами аграрного сектору економіки. Прикладом реалізації системи прикладної інформатизації розповсюдження передового досвіду дає можливість запропонувати до використання такий математичний метод, як нейронні мережі. Нами даний метод був використаний для сегментування регіонів України за рівнем оцінки агрегованої екологічної ефективності та інформаційного забезпечення під час розробки стратегій управління земельними ресурсами та аналізу даних (рис. 2).

Сформовані 9 кластерів, в два 3 яких не потрапила жодна область (див. табл.), що $\epsilon$ великою проблемою у реалізації державної політики, тому що області дев'ятого (Одеська, Херсонська, Дніпропетровська, Донецька, Миколаївська, Запорізька, Луганська) кластерів мають найнижчі 3 точки зору оцінки агрегованої екологічної ефективності характеристики.

Щодо ролі міжнародних партнерів як представників регіональних та глобальних агентів земельних інтересів, то їх участь може бути як пов'язаною із замовленням науковотехнічних послуг у ННВАП, так і з придбанням продукції через ринки їх збуту. Проте всі дані області відносяться до степової природнокліматичної зони України, суттєве поліпшення екологічної та соціально-економічної ситуації в яких можливе лише за умов розвитку зрошуваного землеробства, тобто розвитку інженерної інфраструктури, що і має стати одним із пріоритетів державної політики.

Моделювання організаційних структур управління земельними ресурсами сільськогосподарського призначення в контексті глобалізації дає змогу надати пропозиції щодо його перспектив. Оскільки кожен кластер різний за якісними характеристиками, підходи в адмініструванні даними проблемами будуть різні $з$ боку держави як агента земельних інтересів. Тому дослідження особливостей даних підходів і пошук перспектив національного землекористування і $є$ предметом наших подальших досліджень.

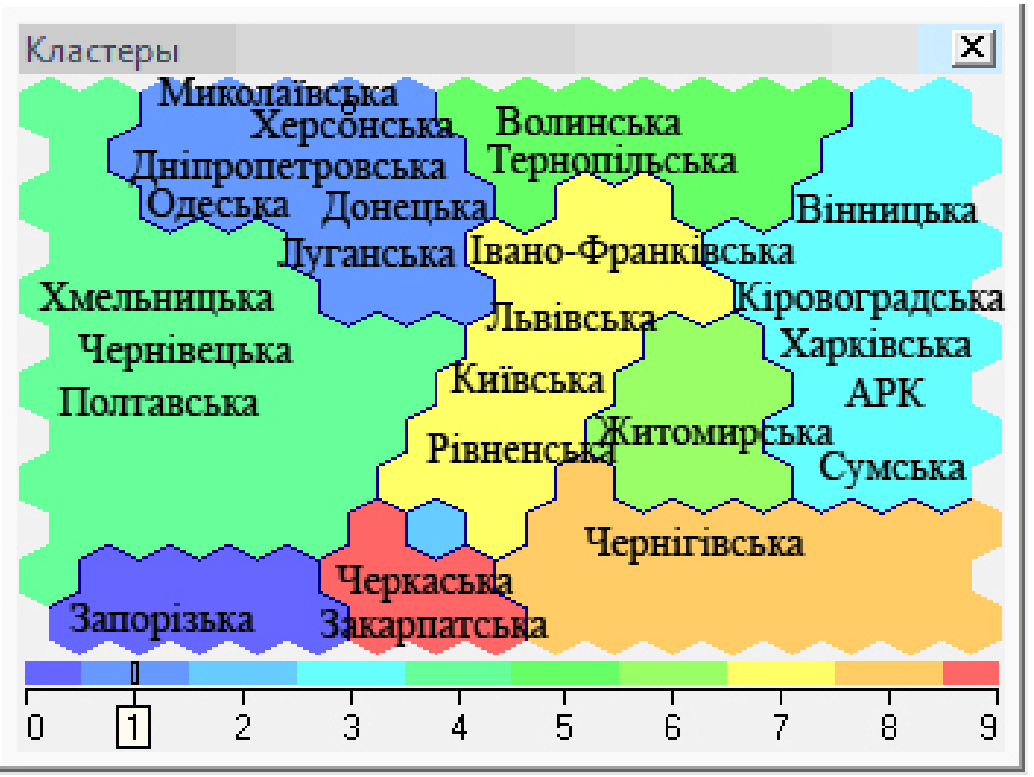

Рис. 2. Кластери регіонів Украйни за оцінки агрегованої екологічної ефективності управління земельними ресурсами на рівні Украӥни за даними 2010 р. * *розроблено автором 


\section{ЕКОНОМІКА}

Характеристика кластерів регіонів, отриманих у результаті побудови СОК за оцінкою агрегованої екологічної ефективності управління земельними ресурсами на рівні Украӥни за даними 2014 р. *

\begin{tabular}{|c|c|c|}
\hline № кластеру & Перелік регіонів, які увійшли & Характеристика \\
\hline $\begin{array}{c}1 \\
\text { (червоний) }\end{array}$ & Закарпатська, Черкаська & $\begin{array}{c}\text { Кластер характеризується найліпшим станом } \\
\text { регіонів, високим рівнем майже всіх аналізованих } \\
\text { показників } \\
\end{array}$ \\
\hline $\begin{array}{c}2 \\
\text { (помаран- } \\
\text { чевий) }\end{array}$ & Чернігівська & $\begin{array}{c}\text { Для кластеру характерні вище за середні показники } \\
\text { критерію відтворення, нижче за середні показники } \\
\text { критерію відтворення та висока амплітуда оцінки } \\
\text { критерію сталість }\end{array}$ \\
\hline $\begin{array}{c}3 \\
\text { (жовтий) }\end{array}$ & $\begin{array}{c}\text { Івано-Франківська, Львівська, } \\
\text { Київська, Рівненська }\end{array}$ & $\begin{array}{c}\text { Для кластеру характерні середні показники } \\
\text { критерію відтворення та вище за середні показники } \\
\text { оцінки критерію сталість }\end{array}$ \\
\hline $\begin{array}{c}4 \\
\text { (салатний) }\end{array}$ & $\begin{array}{c}\text { Хмельницька, Чернівецька, } \\
\text { Полтавська }\end{array}$ & $\begin{array}{c}\text { Практично всі показники даного кластеру вище за } \\
\text { середні }\end{array}$ \\
\hline 5 (зелений) & $\begin{array}{c}\text { Волинська, Тернопільська, } \\
\text { Житомирська }\end{array}$ & Середній стан \\
\hline $\begin{array}{c}6 \\
\text { (бірюзовий) }\end{array}$ & 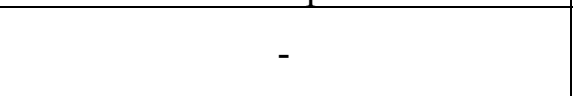 & Стан нижче середнього \\
\hline $\begin{array}{c}7 \\
\text { (блакитний) }\end{array}$ & $\begin{array}{c}\text { Вінницька, Кіровоградська, АРК, } \\
\text { Сумська, Харківська }\end{array}$ & $\begin{array}{c}\text { Практично всі показники даного кластеру нижче за } \\
\text { середні. }\end{array}$ \\
\hline $\begin{array}{c}8 \\
\text { (світлосиній) }\end{array}$ & & $\begin{array}{l}\text { Низький рівень усіх показників оцінювання. } \\
\text { Регіони у кризовому стані. }\end{array}$ \\
\hline $\begin{array}{c}9 \\
\text { (синій) }\end{array}$ & $\begin{array}{c}\text { Миколаївська, Запорізька, } \\
\text { Луганська, Херсонська, Одеська, } \\
\text { Дніпропетровська, Донецька }\end{array}$ & $\begin{array}{c}\text { Дуже низький рівень майже всіх показників } \\
\text { оцінювання. Регіон у кризовому стані }\end{array}$ \\
\hline
\end{tabular}

*розроблено автором

Спільні інвестиції держави та мікро- i мініагентів, наприклад, у поліпшення меліоративного стану земель призводять не тільки до підвищення землевіддачі та відповідно доходів даних агентів, але й підвищення вартості (нормативної оцінки) даних земель, тобто і можливостей залучення інвестицій, і отримання більшої орендної плати. За авторським баченням, доцільним $є$ кооперування держави 3 приватним бізнесом для вирішення проблем охорони грунтів, збільшення обсягів експорту, гармонізації вітчизняної системи управління земельними ресурсами до кращих світових аналогів.

Напрями (принципи) розвитку ДПП в системі землекористування:

А) агрохімічний - сприяння ефективному використанню земельних угідь через агрохімічне забезпечення агровиробників на розгалуженій науково-дослідницькій базі;

В) меліоративний - оптимізація структури сільськогосподарських земель та посівів через участь усіх зацікавлених сторін у меліоративних проектах на паритетній основі;

С) логістичний - раціоналізація землекорис- тування на основі випереджаючого розвитку системи логістичного забезпечення агровиробництва;

D) збутовий - активізація діяльності щодо просування продукції під загальнодержавними або регіональними брендами аграрної продукції, системи утилізації та глибокої переробки основної, додаткової та побічної продукції на аналітико-консультаційній платформі громадських організацій та галузевих асоціацій.

Висновок. Розроблено кластерну модель дуалістичного (традиційна та органічна продукція) розвитку землекористування в Україні. Принциповою відмінністю від існуючих моделей є наявність Національного науково-виробничого агроекологічного парку, регіональних наукових (економічних) центрів розвитку сільських територій та зміщення акценту ролі держави на реалізацію економічних функцій як агента земельних інтересів. Застосовано математичний метод нейронних мереж для сегментування регіонів України за рівнем оцінки агрегованої екологічної ефективності та інформаційного забезпечення під час розробки стратегій управ- 


\section{ЕКОНОМІКА}

ління земельними ресурсами та аналізу даних. Запропоновано концепцію розвитку державноприватного партнерства в системі землекористування, що заснована на агрохімічному, меліоративному, логістичному та збутовому напрямах та має на меті забезпечення поєднання можливостей мікро-, мініагентів, спільних

\section{БІБЛІОГРАФІЯ}

1. Гуторов О. I. Економіко-екологічна оцінка сільськогосподарських земель та проблеми їх сталого використання / O.I. Гуторов [Електронний ресурс]. - Режим доступу: http://www.nbuv.gov.ua/portal/chem_biol/Agroin/2 010_1-3/GUTOROV.pdf.

2. Дієсперов В. С. Селянам - бути хазяями сільських територій / Дієсперов В.С. // Агроінком. 2010. - № 1-3. - C. 7-12.

3. Зось-Kiop M. В. Національні та інтеграційні аспекти управління земельними ресурсами аграрного сектора економіки : [монографія] / Зось-Кіор М. В. - Запоріжжя: "Інтер-М", 2015. 348 c.

4. Покотилова В. I. Кластерна стратегія інноваційного розвитку агропродовольчого комплексу [Електронний ресурс] / B.I. Покотилова. - Режим доступу: http://www.nbuv.gov.ua/portal/Chem_Biol/Tavnv/ 2009_64/64_47.pdf.

5. Про наукові парки: Закон України: [Електронний ресурс]. - Режим доступу: http://zakon2.rada.gov.ua/laws/show/156317/print1401884965984429

6. Саблук П. Т. Міжгалузеві економічні відносини в Україні / П.Т. Саблук, М.Я. МесельВеселяк, М.М. Федоров, М.І. Кісіль; за ред. П. Т. Саблука // Організаційно-економічна модернізація аграрної сфери: наук. доп. - К.: ННЦ IAЕ, 2011. - С. 325-329.

7. Статівка Н. В. Удосконалення системи державного регулювання розвитку земельних відносин / Статівка Н. В. // Теорія та практика агентів та держави, в тому числі із залученням коштів регіональних і глобальних агентів, на компліментарній основі з приводу раціонального землекористування та підвищення прямих i непрямих доходів всіх представників груп земельних інтересів.

державного управління. - Вип. 1. - 2010. - № 28 [Електронний ресурс]. - Режим доступу : http://www.kbuapa.kharkov.ua/e-book/tpdu/2010$1 / \mathrm{doc} / 3 / 05 . \mathrm{pdf}$

8. Третяк A. M. Нова модель земельного устрою в україні у зв'язку із реформою місцевого самоврядування / А. М. Третяк, В. М. Третяк, О. Я. Панчук // Землеустрій, кадастр і моніторинг земель. - № 2. - 2017. - С. 3-12.

9. Третяк A. M. Земельна реформа в Україні: тенденції та наслідки у контексті якості життя i безпеки аселення: [монографія] / А. М. Третяк, В. М. Третяк, Н. А. Третяк // під заг. ред. А. М. Третяка. - Херсон: Грінь Д.С., 2017. - 522 с.

10. Третяк A. М. Склад, структура та зміст «Програми використання і охорони земель та інших природних ресурсів на територіях об'єднаних територіальних громад» на прикладі Деснянської об'єднаної територіальної громади Козелецького району Чернігівської області : [монографія] / А. М. Третяк, В. М. Третяк, В. О. Леонець, Н. А. Третяк, Н. О. Капінос. Херсон: ОЛДІ-ПЛЮС. - 2016. - 110 с.

11. Управління комплексним розвитком агропромислового виробництва i сільських територій: моногр. / за ред. П.Т. Саблука і М.Ф. Кропивка - К.: ННЦ IАЕ, 2011. - С. 450.

12. Ярошенко I. В. Проблемні питання реалізації реформи децентралізації влади в Україні / I. В. Ярошенко, І. Б. Семигуліна // Проблеми економіки. - № 4. - 2015. - С. 177-187. 